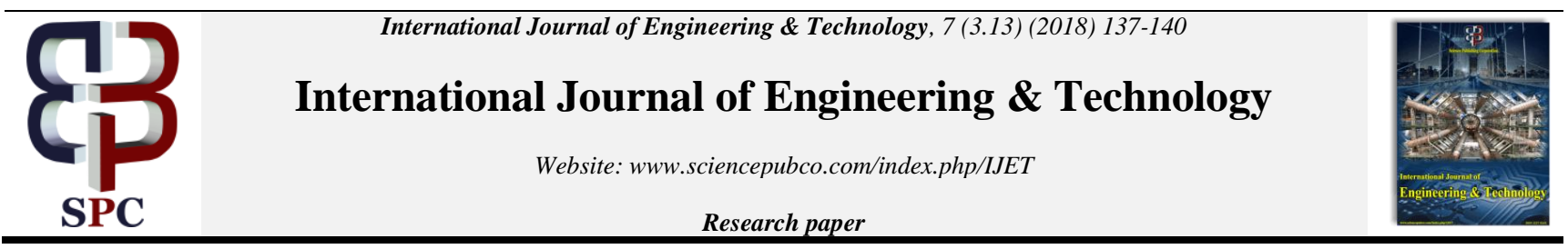

\title{
The Empirical Study on Digital Literacy from the Viewpoint of Digital Accessibility
}

\author{
WookJoon Sung ${ }^{1 *}$ \\ ${ }^{1}$ Graduate School of Public Policy \& Information Tech., \\ Seoul National University of Science \&Technology, Seoul, South Korea \\ *Corresponding author E-mail: wjsung@seoultech.ac.kr
}

\begin{abstract}
The purpose of this study is to empirically analyze the effect of motivation factor in digital literacy. In particular, we examine the cumulative and recursive model of digital access, and examine the causal path of motivation factor to digital usages by analyzing the effects of motivation access on material access, skill access, and usage access. For the analysis, we used 'the digital divide index and actual survey' data of National Information Society Agency (NIA). The analytical model used the structural equation, and the statistics program used SPSS 23 and Amos 23. The results show that the motivation factor for digital literacy has a significant effect on material access, skill access and usage access. Policies that take into account motivations factors in digital literacy need to be strengthened.
\end{abstract}

Keywords: Digital literacy, Digital divide, material access, digital access, motivation, digital skill, digital usage

\section{Introduction}

The transition to smart society, which began with the introduction of smart devices, is promoting new changes in the areas of politics, economy, society, and culture with the development of smart technologies such as Big Data, cloud computing, and Internet of Things.

However, despite these changes, the problems that have persisted since the information age are still continuing. The development of new digital technologies has created social problems due to the digital divide as much as the convenience of new services. Digital literacy is an essential capability to live in the digital age, but it can deepen inequality in all spheres of society, economy and politics due to the digital divide. In other words, the emergence of smart devices including smartphones and the increase of various contents and services delivered over the Internet can increase the possibility of new opportunities. However, in addition to the existing PC-based digital divide, smart-based digital divide may deepen social inequalities.

How can we solve the problem of digital inequality caused by the difference in ability to utilize digital devices as basic human capital? One of the most noteworthy issues in the field of digital divide research is the motivational factors that work before material access or digital usages. Therefore, the purpose of this study is to analyze the effects of motivational factors on the usage of digital services.

\section{Literature Review}

The digital divide was defined as the gap between those who do and those do not have access to computer and the Internet [1][2][3]. Until now, most studies on the information gap have focused on the information gap of socioeconomic dimension such as age, sex, income, education, and occupation [1][2][3][4][5][6][7][8][9][10][11][12][13][14][15][16][17][18][1 9][20][21][22].

However, for a deeper understanding of the digital divide, an approach based on digital access is needed. The digital divide is a complex concept that includes various access. Digital access is a multi-dimensional concept, which means various accessibility in terms of motivational access, material access and usage. In general, digital accessibility consists of material or physical access related to the capabilities of the Internet or information devices, skill access, including the ability to handle hardware and software, and usage access, including various uses and utilization of digital contents [1][2][3]. These four successive stages or kinds of access are supposed to be cumulative. The improvement in digital accessibility at each stage affects not only the next step but also the subsequent steps. Based on the above discussion, we will use the concept of digital accessibility in understanding and defining digital literacy as shown in [Fig.1].

This study aims to empirically analyze four levels of accessibility of digital literacy. In particular, we will positively confirm the path that material access, skill access, and usage access are spreading around motivational access, which has not been covered much in the digital divide research. 


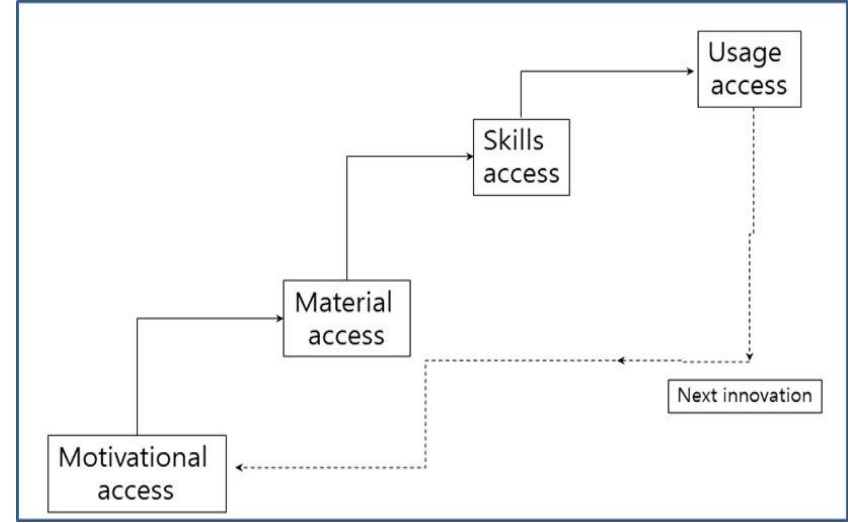

[Fig. 1] Continuity of accessibility in digital technology

\section{Research Framework and Methods}

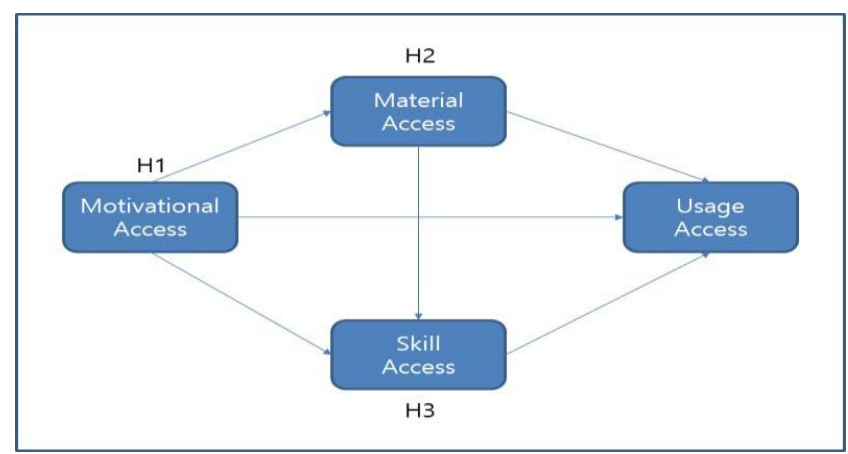

[Fig. 2] Conceptual Framework

The research question of this study is "How does the motivational access in digital literacy affect material access, skill access, and usage access?" The specific hypothesis of this study related to the effects of motivational factors on information literacy for verifying research problems is as follows.

H1. Motivational access factor will have a positive impact on material access, skill access, and usage access.

H2. Material access will have a positive impact on skill access and usage access.

H3. The technical approach will have a positive impact on usage access.

This study uses data gather from the "Survey on the digital divide" in the National Information Agency (NIA) in 2015. This data is the national approval statistics, which can be used to increase the reliability of the collected data and the validity of the data collection process. The main variables and measurement methods used in the study are as follows.

Table.1. Main Variables and Measurements

\begin{tabular}{|c|c|}
\hline $\begin{array}{c}\text { Smart device based } \\
\text { Digital Literacy }\end{array}$ & $\begin{array}{c}\text { Variable Description and } \\
\text { measurements }\end{array}$ \\
\hline $\begin{array}{l}\text { motivational access: recogniz- } \\
\text { ing the necessity (importance) } \\
\text { of smartphone }\end{array}$ & $\begin{array}{l}\text { (Smart phone importance in each of the } \\
\text { following items), } \\
\text { 1. Economic activities (including con- } \\
\text { sumption activities such as purchases) } \\
\text { 2. Leisure (hobby) and cultural life } \\
\text { 3. Social activities } \\
\text { 4. Interpersonal Relationship (Main- } \\
\text { taining relationship with an old person } \\
\text { and meeting new person) } \\
\text { 5. Business or academic activity } \\
\text { 6. Know the news or news } \\
\text { 7. Getting information and knowledge } \\
\text { * Likert 4-points scale }\end{array}$ \\
\hline
\end{tabular}

\begin{tabular}{|c|c|}
\hline Material access & $\begin{array}{l}1 \text { Whether to have a smartphone }(1= \\
\text { hold, } 2=\text { not show) } \\
2 \text { Whether you have a smart pad }(1= \\
\text { hold, } 2=\text { not show }) \\
4 \text { Other mobile smart devices }(1=\text { hold, } \\
2=\text { not show }) \\
\text { = Retain smart devices }=1 \text {, No smart } \\
\text { devices }=0\end{array}$ \\
\hline Skill access & $\begin{array}{l}\text { (Basic operation ability of smart device) } \\
\text { 1. Basic device configuration } \\
\text { 2. Wireless network and Bluetooth } \\
\text { settings } \\
\text { 3. Move files to your computer } \\
\text { 4. File transfer } \\
\text { 5. Installing and using necessary apps } \\
\text { 6. Malicious code inspection and treat- } \\
\text { ment } \\
\text { 7. Writing documents or materials } \\
\text { * Likert 4-points scale }\end{array}$ \\
\hline \multirow{3}{*}{$\begin{array}{l}\text { Usage access } \\
\text {-Social participation } \\
\text {-Economic activity } \\
\text {-Human networking }\end{array}$} & $\begin{array}{l}\text { (Degree of information sharing/human } \\
\text { relations and networking activities) } \\
\text { 1. Internet information posting } \\
\text { 2. Internet information sharing } \\
\text { 3. Maintaining existing relationships, } \\
\text { forming new relationship networks } \\
\text { * Likert 4-points scale }\end{array}$ \\
\hline & $\begin{array}{l}\text { (Degree of social participation activity) } \\
\text { 1. Social Concerns (Public Issues) opin- } \\
\text { ion Expression } \\
\text { 2.Suggestions or suggestions for gov- } \\
\text { ernment / local governments / public } \\
\text { institutions } \\
\text { 3. Social contribution activities such as } \\
\text { donation / service / politics } \\
\text { 4. Community activities related to local } \\
\text { / political / social participation Partici- } \\
\text { pate in online voting, polling, signing, } \\
\text { etc. } \\
\text { * Likert 4-points scale }\end{array}$ \\
\hline & $\begin{array}{l}\text { (Degree of economic opportunity activi- } \\
\text { ty) } \\
\text { 1. Activities that help you get a job or } \\
\text { change your job } \\
\text { 2. Activities that help start a business or } \\
\text { operate a business } \\
\text { 3. Related information to help increase } \\
\text { income activity } \\
\text { 4. Activities that help reduce costs } \\
\text { * Likert 4-points scale }\end{array}$ \\
\hline
\end{tabular}

The structural equation model was used for the analysis of the research problem, and the program used were SPSS 23.0 and AMOS 23.00.

\section{Finding and Discussion}

\subsection{Descriptive Statistics}

The total sample size of the survey participants is 5,500. According to the demographic characteristics, the age was less than 10 years, $0.6 \%$ ( 31 persons), $15.3 \%$ ( 841 persons) in their teens, $13.7 \%$ (756 persons) in their 20s, $16.8 \%$ (924 persons) (647 persons) in their 60 s and $6.6 \%$ (364 people in their 70 s or older). Sex is $50 \%$ (2749) for males and $50 \%$ (2751) for females. The final education level is $14.7 \%$ (809 students) in elementary school graduation, $16.9 \%$ (930 students) in middle school graduation, $40.7 \%$ (2238 students) in high school graduation and 27.5\% (1512 students) in university graduation. $60 \%$ of the occupations are occupations, and $40 \%$ are unemployed, including the full-time housewife. The average monthly household income of households is $1.6 \%, 500,000$ won is $4.8 \%, 100-100$ thousand won is $13.1 \%$, 200-3 million won is $23.2 \%$, 300-4 million won is $28.9 \%$, $400-5$ million won is $15.5 \%, 7.9 \%$ for $500-600,000$ won, and $3.3 \%$ for over 6 million won. $78.3 \%$ (4307 people) have smartphones and $21.7 \%$ (1193 people) are not. 
The main results of the descriptive statistics of other variables are shown in the table below.

Table. 2. Descriptive Statistics

\begin{tabular}{|c|c|c|c|c|c|}
\hline & $\mathrm{N}$ & Min & Max & Mean & S.D \\
\hline $\begin{array}{c}\text { Motivational access } \\
(7 \text { items })\end{array}$ & 5500 & 1.00 & 4.00 & 2.994 & .61866 \\
\hline $\begin{array}{c}\text { Skill access } \\
(7 \text { items })\end{array}$ & 5500 & 1.00 & 4.00 & 2.459 & 1.02058 \\
\hline $\begin{array}{c}\text { Human networking } \\
(4 \text { items })\end{array}$ & 4369 & 1.00 & 4.00 & 2.371 & .79484 \\
\hline $\begin{array}{c}\text { Social Participation } \\
(5 \text { items })\end{array}$ & 4369 & 1.00 & 4.00 & 1.578 & .71212 \\
\hline $\begin{array}{c}\text { Economic activities } \\
(4 \text { items })\end{array}$ & 4369 & 1.00 & 4.00 & 1.759 & .80627 \\
\hline $\mathrm{N}$ & 4369 & & & & \\
\hline
\end{tabular}

\subsection{Validity and Reliability of Measurements}

Before the path analysis, the validity and reliability test of the measurement tool were performed. First, confirmatory factor analysis was performed to check the validity of specific tools. The main contents of AVE (Average variance extraction) and C.R (Concept reliability) according to confirmatory factor analysis are shown in the table below.

Table.3. Confirmatory Factor Analysis

\begin{tabular}{|c|c|c|c|c|c|c|c|}
\hline & $\begin{array}{c}\text { Human } \\
\text { net- } \\
\text { working }\end{array}$ & $\begin{array}{l}\text { Social } \\
\text { participa- } \\
\text { tion }\end{array}$ & $\begin{array}{c}\text { Eco- } \\
\text { nomic } \\
\text { activi- } \\
\text { ty }\end{array}$ & $\begin{array}{c}\text { Skill } \\
\text { access }\end{array}$ & $\begin{array}{l}\text { Moti- } \\
\text { va- } \\
\text { tional } \\
\text { access } \\
\end{array}$ & AVE & C.R. \\
\hline $\begin{array}{c}\text { Human } \\
\text { network- } \\
\text { ing }\end{array}$ & 1 & & & & & 0.522 & 0.801 \\
\hline $\begin{array}{l}\text { Social } \\
\text { participa- } \\
\text { tion }\end{array}$ & 0.293 & 1.000 & & & & 0.679 & 0.939 \\
\hline $\begin{array}{c}\text { Economic } \\
\text { activity }\end{array}$ & 0.220 & 0.407 & 1.000 & & & 0.649 & 0.889 \\
\hline $\begin{array}{c}\text { Skill } \\
\text { access }\end{array}$ & 0.254 & 0.072 & 0.070 & 1.000 & & 0.682 & 0.945 \\
\hline $\begin{array}{c}\text { Motiva- } \\
\text { tional } \\
\text { access }\end{array}$ & 0.082 & 0.020 & 0.076 & 0.152 & 1 & 0.43 & 0.912 \\
\hline
\end{tabular}

\subsection{Path analysis results}

The model fit was analyzed using the absolute fit index (GFI 0.923, RMR 0.051, RMSEA 0.055), incremental fit index (NFI 0.942, RFI 0.932, IFI 0.946, CFI 0.946, TLI 0.936), Parsimonious fit index 0.904), all of which are shown as suitable.

The main results of path analysis are as follows. First, motivational access is positively significant for both material access, skill access, usage access (social participation, economic activity, and human networking). Second, material access is positively (+) significant for skill access, usage access (social participation, economic activity, human networking).

The results of this analysis show the continuity and accumulation of accessibility in digital literacy as discussed above. In other words, motivational factors in the use of devices and services based on new technologies can contribute to digital literacy by increasing skill access and usage accesses related to digital accessibility.
Table.4. Results of path analysis

\begin{tabular}{|c|c|c|c|c|c|c|c|}
\hline & & & $\begin{array}{l}\text { Esti- } \\
\text { mate }\end{array}$ & $\begin{array}{l}\text { stand- } \\
\text { ardized } \\
\text { Esti- } \\
\text { mate }\end{array}$ & S.E. & C.R. & $\mathrm{P}$ \\
\hline $\begin{array}{c}\text { Material } \\
\text { access }\end{array}$ & $\leftarrow$ & $\begin{array}{c}\text { Motiva- } \\
\text { tional } \\
\text { access }\end{array}$ & 0.071 & 0.19 & 0.006 & 11.691 & $* * *$ \\
\hline $\begin{array}{c}\text { Skill } \\
\text { access }\end{array}$ & $\leftarrow$ & $\begin{array}{c}\text { Materi- } \\
\text { al ac- } \\
\text { cess }\end{array}$ & 1.01 & 0.265 & 0.056 & 17.926 & $* * *$ \\
\hline $\begin{array}{c}\text { Skill } \\
\text { access }\end{array}$ & $\leftarrow$ & $\begin{array}{c}\text { Motiva- } \\
\text { tional } \\
\text { access }\end{array}$ & 0.487 & 0.34 & 0.024 & 20.289 & $* * *$ \\
\hline $\begin{array}{c}\text { Social } \\
\text { participa- } \\
\text { tion }\end{array}$ & $\leftarrow$ & $\begin{array}{c}\text { Materi- } \\
\text { al ac- } \\
\text { cess }\end{array}$ & 0.256 & 0.067 & 0.062 & 4.105 & $* * *$ \\
\hline $\begin{array}{l}\text { Economic } \\
\text { activity }\end{array}$ & $\leftarrow$ & $\begin{array}{c}\text { Materi- } \\
\text { al ac- } \\
\text { cess }\end{array}$ & 0.322 & 0.082 & 0.063 & 5.088 & $* * *$ \\
\hline $\begin{array}{c}\text { Social } \\
\text { participa- } \\
\text { tion }\end{array}$ & $\leftarrow$ & $\begin{array}{c}\text { Skill } \\
\text { access }\end{array}$ & 0.23 & 0.23 & 0.019 & 12.349 & $* * *$ \\
\hline $\begin{array}{l}\text { Economic } \\
\text { activity }\end{array}$ & $\leftarrow$ & $\begin{array}{c}\text { Skill } \\
\text { access }\end{array}$ & 0.163 & 0.159 & 0.019 & 8.69 & $* * *$ \\
\hline $\begin{array}{c}\text { Social } \\
\text { participa- } \\
\text { tion }\end{array}$ & $\leftarrow$ & $\begin{array}{c}\text { Motiva- } \\
\text { tional } \\
\text { access }\end{array}$ & 0.058 & 0.04 & 0.026 & 2.217 & $* * *$ \\
\hline $\begin{array}{l}\text { Economic } \\
\text { activity }\end{array}$ & $\leftarrow$ & $\begin{array}{c}\text { Motiva- } \\
\text { tional } \\
\text { access }\end{array}$ & 0.291 & 0.198 & 0.027 & 10.764 & $* * *$ \\
\hline $\begin{array}{l}\text { Human } \\
\text { Network- } \\
\text { ing }\end{array}$ & $\leftarrow$ & $\begin{array}{c}\text { Materi- } \\
\text { al ac- } \\
\text { cess }\end{array}$ & 0.238 & 0.051 & 0.07 & 3.41 & $* * *$ \\
\hline $\begin{array}{l}\text { Human } \\
\text { Network- } \\
\text { ing }\end{array}$ & $\leftarrow$ & $\begin{array}{c}\text { Motiva- } \\
\text { tional } \\
\text { access }\end{array}$ & 0.18 & 0.103 & 0.029 & 6.117 & $* * *$ \\
\hline $\begin{array}{l}\text { Human } \\
\text { Network- } \\
\text { ing }\end{array}$ & $\leftarrow$ & $\begin{array}{c}\text { Skill } \\
\text { access }\end{array}$ & 0.547 & 0.447 & 0.022 & 24.69 & $* * *$ \\
\hline \multicolumn{8}{|c|}{$\begin{array}{c}\text { Absolute fit index: GFI } 0.923, \text { RMR } 0.051, \text { RMSEA } 0.055 \\
\text { Incremental fit index: NFI } 0.942 \text {, RFI } 0.932 \text {, IFI } 0.946, \text { CFI } 0.946, \text { TLI } \\
0.936 \\
\text { Parsimonious fit index: AGFI } 0.904\end{array}$} \\
\hline
\end{tabular}

\section{Conclusion}

This study is an empirical study on digital literacy. In the meantime, research on digital literacy is relatively lacking in studying what digital literacy is, mainly focusing on the digital divide. This study divides digital literacy into four layers by understanding digital literacy in terms of information accessibility. And that the four digital information accessibilities are continuous and cumulative rather than discontinuous.

In order to verify the theoretical discussion on the characteristics of digital literacy, we conducted empirical analysis through the data of NIA. As a result of the analysis, all major research hypotheses were adopted. First, motivational access factor has a positive impact on material access, skill access, and usage access. Second, material access has a positive impact on skill access and usage access. Third, the technical approach had a positive impact on usage access. More active research on motivational access, which has not been noticed, is needed in the future.

\section{Acknowledgement}

This work was supported by the Ministry of Education of the Republic of Korea and the National Research Foundation of Korea (NRF-2017S1A5A2A02068913) 


\section{References}

[1] Jan A.G.M.van Dijk. (2005). The Deepening Divide. SAGE Publications: Thousand Oaks, London, New Delhi

[2] OECD (2001), Understanding the Digital Divide, Paris

[3] Nicole Zillen and Mirko Marr. (2013). The digital divide in Europe in Massimo Ragnedda and Glenn W. Muschert (ed.). The Digita Divide: The internet and social inequality in international perspective. Routledge.

[4] James Witte, Marissa Kiss and Randy Lynn (2013). The Interne and social inequalities in the U.S. in Massimo Ragnedda and Glenn W. Muschert (ed.). The Digital Divide: The internet and social inequality in international perspective. Routledge

[5] Mito Akiyoshi, Motohiro Tsuchiya and Takako Sano (2013) Missing in the midst of abundance: The case of broadband adoption in Japan. in Massimo Ragnedda and Glenn W. Muschert (ed.). The Digital Divide: The internet and social inequality in international perspective. Routledge.

[6] Bernardo Sorj (2013). The digital divide in Brazil: Conceptual research and policy challenges. in Massimo Ragnedda and Glenn W. Muschert (ed.). The Digital Divide: The internet and social inequality in international perspective. Routledge.

[7] Inna F. Deviatko (2013). Digitizing Russia: The uneven pace of progress toward ICT equality. in Massimo Ragnedda and Glenn W. Muschert (ed.). The Digital Divide: The internet and social inequality in international perspective. Routledge.

[8] P. Vigneswara Ilavarasan (2013). The digital divide in India: Inferences from the information and communication technology workforce. in Massimo Ragnedda and Glenn W.

[9] Shu-Fen Tseng and Yu-Ching You (2013). The digital divide in China, Hong Kong and Taiwan: The barriers of first order and second order digital divide. in Massimo Ragnedda and Glenn W. Muschert (ed.). The Digital Divide: The internet and social inequality in international perspective. Routledge.

[10] Danica Radovanovic (2013). The Internet and digital divide in South Eastern Europe: Connectivity does not end the digital divide, skills do. in Massimo Ragnedda and Glenn W. Muschert (ed.). The Digital Divide: The internet and social inequality in international perspective. Routledge.

[11] Monica Barbovschi and Bianca Balea (2013). Closing the gap, are we there yet?: Reflections on the persistence of second-level digital divide among adolescents in Central and Eastern Europe. in Massimo Ragnedda and Glenn W. Muschert (ed.). The Digital Divide: The internet and social inequality in international perspective. Routledge.

[12] Veronika Kalmus, Kairi Talves and Pille Pruulmann-Vengerfeldt (2013). Behind the slogan of "e-State": Digital stratification in Estonia. in Massimo Ragnedda and Glenn W. Muschert (ed.). The Digital Divide: The internet and social inequality in international perspective. Routledge.

[13] David M. Faris (2013). Digitally divided we stand: The contribution of digital media to the Arab Spring. in Massimo Ragnedda and Glenn W. Muschert (ed.). The Digital Divide: The internet and social inequality in international perspective. Routledge.

[14] Gustavo Mesch Ilan Talmud and Tanya Kolobov (2013) Explaining digital inequalities in Israel: Juxtaposing the conflict and cultural perspectives. in Massimo Ragnedda and Glenn W. Muschert (ed.). The Digital Divide: The internet and social inequality in international perspective. Routledge.

[15] Hamid Abdollahtan, Mehdi Semati and Mohammd Ahmadi (2013). An analysis of the second-level digital divide in Iran: A case study of University of Tehran undergraduate students. in Massimo Ragnedda and Glenn W. Muschert (ed.). The Digital Divide: The internet and social inequality in international perspective. Routledge.

[16] Daniela Trucco (2013). The digital divide in the Latin American context. in Massimo Ragnedda and Glenn W. Muschert (ed.). The Digital Divide: The internet and social inequality in international perspective. Routledge.

[17] Barney Ware (2013). The Central Asian digital divide. in Massimo Ragnedda and Glenn W. Muschert (ed.). The Digital Divide: The internet and social inequality in international perspective. Routledge.

[18] Manivannan D, Manikandan N.K, Kishore Kumar K. (2018) Survey to improve accessibility for person with disabilities. International Journal of Engineering \&Technology, 7 (1.7): 182185
[19] Md. Aktaruzzaman, Md. Rashedul Huq Shamim, Che Kum Clement 3. (2011). Trends and Issues to integrate ICT in Teaching Learning for the Future World of Education. International Journal of Engineering \& Technology IJET-IJENS 11(3): 114-119

[20] Tomohisa Hirata (2013). The double digital divide and social inequality in Asia: Comparative research on Internet cafes in Taiwan, Singapore, Thailand, and the Philippines. in Massimo Ragnedda and Glenn W. Muschert (ed.). The Digital Divide: The internet and social inequality in international perspective. Routledge.

[21] Gado Alzouma (2013). Dimensions of the mobile divide in Niger. in Massimo Ragnedda and Glenn W. Muschert (ed.). The Digital Divide: The internet and social inequality in international perspective. Routledge

[22] Sung, Wookjoon (2014) A study on the digital literacy and the digital divide in the smart society. Korean Society and Public Administration. Vol 25(2): 53-75 